\title{
Labdane-Type Diterpenoids from the Rhizomes of Hedychium coronarium Inhibit Lipopolysaccharide-Stimulated Production of Pro- inflammatory Cytokines in Bone Marrow-Derived Dendritic Cells
}

\author{
Phan Van Kiem, ${ }^{b}$ Hoang Le Tuan Anh, ${ }^{b}$ Nguyen Xuan Nhiem, ${ }^{a, b}$ Chau Van Minh, ${ }^{b}$ \\ Nguyen Thi Kim Thuy, ${ }^{b, c}$ Pham Hai Yen, ${ }^{b}$ Dan Thuy Hang, ${ }^{,}$Bui Huu Tai,${ }^{a, b}$ \\ Vivek Bhakta Mathema, ${ }^{d}$ Young-Sang Koh, ${ }^{d}$ and Young Ho Kim $* a$ \\ ${ }^{a}$ College of Pharmacy, Chungnam National University; Daejeon 305-764, Korea: ${ }^{b}$ Institute of Marine Biochemistry, \\ Vietnam Academy of Science and Technology; 18 Hoang Quoc Viet, Caugiay, Hanoi, Vietnam: ${ }^{c}$ Viettri University of \\ Industry; Viettri, Phutho, Vietnam: and ${ }^{d}$ School of Medicine and Brain Korea 21 Program, Jeju National University; \\ Jеju 690-756, Korea.
}

Received July 4, 2011; accepted September 22, 2011; published online November 11, 2011

The rhizomes of Hedychium coronarium have been used for the treatment of inflammation, skin diseases, headache, and sharp pain due to rheumatism in traditional medicine. From this plant, two new labdanes, 15-methoxylabda-8(17),11E,13-trien-16,15-olide (1) and 16-methoxylabda-8(17),11E,13-trien-15,16-olide (3), named hedycoronens $A$ and $B$, as well as four known, labda-8(17),11,13-trien-16,15-olide (2), 16-hydroxylabda-8(17),11,13-trien-15,16-olide (4), coronarin A (5), and corronarin E (6) were isolated. Their chemical structures were elucidated by mass, 1D- and 2D-nuclear magnetic resonance (NMR) spectroscopy. They were evaluated for inhibitory effects on the lipopolysaccharide (LPS)-stimulated production of pro-inflammatory cytokines in bone marrow-derived dendritic cells. Among of them, compounds $1-3$ were potent inhibitors of LPS-stimulated interleukin-6 (IL-6) and IL-12 p40, with $\mathrm{IC}_{50}$ ranging from $4.1 \pm 0.2$ to $9.1 \pm 0.3 \mu \mathrm{M}$. Compounds 1 and 3 showed moderate inhibitory activity on the tumor necrosis factor- $\alpha$ (TNF- $\alpha$ ) production with $\mathrm{IC}_{50}$ values of $46.0 \pm 1.3$ and $12.7 \pm 0.3 \mu \mathrm{M}$. The remains of compounds showed inactivity. These results warrant further studies concerning the potential anti-inflammatory benefits of labdane-diterpenes from $H$. coronarium.

Key words Hedychium coronarium; hedycoronen A; hedycoronen B; tumor necrosis factor- $\alpha$; interleukin- 6 ; interleukin-12

Numerous molecules are involved in the induction and maintenance of the inflammatory response. In addition to pivotal cytokines such as interleukin-1 (IL-1), -6, -12, and tumor necrosis factor- $\alpha$ (TNF- $\alpha$ ), prostaglandins, and nitric oxide are important chemical mediators of inflammation. TNF- $\alpha$ is a well-characterized pro-inflammatory cytokine released primarily from monocytes and macrophages upon invasion of the host by a wide variety of pathogens. It plays a crucial role in host defense and in the inflammatory response. Although it has numerous beneficial roles in immune regulation, it has also been implicated in the pathogenesis of both acute and chronic inflammatory disease. ${ }^{1)}$

IL-6 is a particularly interesting molecule because it has both pro- and anti-inflammatory effects. It has been implicated in many inflammatory diseases in both adults and neonates. ${ }^{2)}$ The IL-6 system promotes inflammatory events by stimulating the activation and proliferation of lymphocytes, differentiation of B cells, leukocyte recruitment, and the induction of an acute phase protein response in the liver. ${ }^{3)}$

IL-12 plays a central role in the initiation and regulation of cellular immunity. It is involved in type-1 helper T-cell-mediated inflammation as part of the normal immune response, as well as inflammatory diseases, including rheumatoid arthritis, asthma, psoriasis, and Crohn's disease. ${ }^{4-6)}$

Hedychium coronarium (Zingiberaceae) is widely cultivated in Vietnam, India, and Southeast Asian countries. It is a perennial rhizomatous herb growing at an altitude of $1000-2200 \mathrm{~m}$. The rhizomes of $H$. coronarium have been used for the treatment of inflammation, skin diseases, headache, and sharp pain due to rheumatism in traditional medi-

\footnotetext{
* To whom correspondence should be addressed. e-mail: yhk@cnu.ac.kr

cine in Vietnam. Previous phytochemical investigation of $H$. coronarium has resulted in the identification of a number of labdane diterpenes, which were proved to be the main components. $^{7-10)}$ Labdane diterpenes occur in several plants of the Zingiberaceae family and have been reported to possess anti-inflammatory properties. ${ }^{11,12)}$ Interestingly, our extensive phytochemical study of the rhizomes of $H$. coronarium led to the isolation of two new and four known labdane-type diterpenoids. These six labdanes $(\mathbf{1}-\mathbf{6})$ were evaluated for the lipopolysaccharide (LPS)-stimulated production of pro-inflammatory cytokines in bone marrow-derived dendritic cells.

\section{Results and Discussion}

The rhizomes of $H$. coronarium were extracted with methanol and fractionated with chloroform, ethyl acetate, and water. From the chloroform layer and by using combined chromatographic separations, two new and four known compounds were isolated. Their structures were elucidated using physicochemical and spectroscopic methods.

Compound 1 was obtained as a colorless viscous oil. Its basic ion peak at $m / z 331[\mathrm{M}+\mathrm{H}]^{+}$was observed on positiveion electrospray ionization mass spectrometry (ESI-MS), and high-resolution electrospray ionization mass spectroscopy (HR-ESI-MS) analysis revealed the molecular formula to be $\mathrm{C}_{21} \mathrm{H}_{30} \mathrm{O}_{3}$, with a cluster ion peak at $\mathrm{m} / z$ 331.2268 $[\mathrm{M}+\mathrm{H}]^{+}$ (Calcd for $\mathrm{C}_{21} \mathrm{H}_{31} \mathrm{O}_{3}$ : 331.2273). The ${ }^{1} \mathrm{H}-\mathrm{NMR}$ spectrum of 1 (in chloroform- $d_{1}$ ) showed the following signals: three tertiary methyl groups at $\delta_{\mathrm{H}} 0.84,0.87$, and 0.89 (each $3 \mathrm{H}, \mathrm{s}$ ); one methoxy group at $\delta_{\mathrm{H}} 3.56(\mathrm{~s})$; and five olefinic protons at $\delta_{\mathrm{H}} 4.48$, 4.76, 6.10, 6.78, and 6.96 (see Table 1). The ${ }^{13} \mathrm{C}-\mathrm{NMR}$ and 
Table 1. The NMR Spectroscopic Data of $\mathbf{1}$ and $\mathbf{3}$

\begin{tabular}{|c|c|c|c|c|}
\hline \multirow{2}{*}{ Position } & \multicolumn{2}{|c|}{1} & \multicolumn{2}{|c|}{3} \\
\hline & $\delta_{\mathrm{C}}^{a, b)}$ & $\delta_{\mathrm{H}}^{a, c)}(J$ in $\mathrm{Hz})$ & $\delta_{\mathrm{C}}{ }^{a, b)}$ & $\delta_{\mathrm{H}}^{a, c)}(J$ in $\mathrm{Hz})$ \\
\hline \multirow[t]{2}{*}{1} & 40.86 & $1.00(\mathrm{dt}, 3.5,13.0)$ & $40.96 / 41.02$ & 1.08 \\
\hline & & 1.45 & & 1.41 \\
\hline \multirow[t]{2}{*}{2} & 19.09 & 1.42 & $19.01 / 19.06$ & 1.43 \\
\hline & & 1.50 & & 1.52 \\
\hline \multirow[t]{2}{*}{3} & 42.29 & $1.18(\mathrm{dt}, 3.5,12.5)$ & 42.14 & $1.20(\mathrm{t}, 12.0)$ \\
\hline & & 1.44 & & 1.43 \\
\hline 4 & $33.56 / 33.58$ & & 33.51 & - \\
\hline 5 & $54.72 / 54.74$ & $1.09(\mathrm{dd}, 2.5,12.5)$ & $54.55 / 54.59$ & $1.10(\mathrm{dd}, 2.5,12.5)$ \\
\hline \multirow[t]{2}{*}{6} & 23.36 & 1.39 & $23.23 / 23.24$ & 1.73 \\
\hline & & 1.71 & & \\
\hline \multirow[t]{2}{*}{7} & 36.74 & $2.08(\mathrm{dt}, 5.0,13.0)$ & 36.61 & $2.09(\mathrm{dt}, 5.0,13.5)$ \\
\hline & & 2.43 & & $2.45^{d)}$ \\
\hline 8 & 149.18 & - & $148.83 / 148.87$ & - \\
\hline 9 & $62.28 / 62.30$ & $2.38(\mathrm{~d}, 9.5)$ & $61.96 / 62.05$ & $2.46(\mathrm{~d}, 10.0)$ \\
\hline 10 & $39.36 / 39.39$ & - & $39.50 / 39.58$ & - \\
\hline \multirow[t]{2}{*}{11} & 139.56 & $6.96(\mathrm{dd}, 10.0,16.0)$ & $143.18 / 143.22$ & $6.48(\mathrm{dd}, 10.0,16.0)$ \\
\hline & & & & $6.50(\mathrm{dd}, 10.0,16.0)$ \\
\hline \multirow[t]{2}{*}{12} & $120.29 / 120.31$ & $6.10(\mathrm{~d}, 16.0)$ & $122.71 / 122.76$ & $6.28(\mathrm{~d}, 16.0)$ \\
\hline & & & & $6.29(\mathrm{~d}, 16.0)$ \\
\hline 13 & $131.98 / 132.00$ & - & 159.18 & - \\
\hline 14 & $139.20 / 139.23$ & $6.78(\mathrm{~s})$ & $116.52 / 116.55$ & $5.89(\mathrm{~s})$ \\
\hline 15 & 101.94 & $5.76(\mathrm{~s})$ & 170.68 & - \\
\hline 16 & $169.56 / 169.57$ & - & $102.57 / 102.66$ & $6.00(\mathrm{~s})$ \\
\hline \multirow[t]{2}{*}{17} & $108.49 / 108.53$ & 4.76 (brs) & $108.51 / 108.62$ & $4.37(\mathrm{brs}) / 4.78(\mathrm{brs})$ \\
\hline & & 4.48 (brs) & $108.51 / 108.62$ & $4.43(\mathrm{brs}) / 4.79(\mathrm{brs})$ \\
\hline 18 & 33.56 & $0.89(\mathrm{~s})$ & 33.58 & $0.90(\mathrm{~s})$ \\
\hline 19 & 21.93 & $0.84(\mathrm{~s})$ & 21.91 & $0.87(\mathrm{~s})$ \\
\hline 20 & 15.07 & $0.87(\mathrm{~s})$ & $15.12 / 15.14$ & $0.85(\mathrm{~s})$ \\
\hline 15-OMe & $56.76 / 56.82$ & $3.56(\mathrm{~s})$ & 54.30 & $3.47(\mathrm{~s})$ \\
\hline
\end{tabular}

a) Recorded in $\mathrm{CDCl}_{3}$, b) $\left.125 \mathrm{MHz}, c\right) 500 \mathrm{MHz}, d$ ) overlapped signals, assignments were done by HSQC, HMBC, ${ }^{1} \mathrm{H}-{ }^{1} \mathrm{H}$ COSY, and NOESY experiments.

distortionless enhancement by polarization transfer (DEPT) spectra revealed 21 carbon signals including four methyl, six methylene, six methine, and five quaternary carbons. The ${ }^{1} \mathrm{H}$ - and ${ }^{13} \mathrm{C}-\mathrm{NMR}$ data of $\mathbf{1}$ indicated it was to be a labdanetype diterpenoid, but it exists as an epimeric mixture at C-15. On the other hand, NMR data of $\mathbf{1}$ were similar to those of 15-hydroxylabda-8(17),11,13-trien-16,15-olide ${ }^{13)}$ except for the addition of an methoxy group at $\mathrm{C}$-15. An $\alpha, \beta$-unsaturated $\gamma$-lactone with a methyoxy group at $\gamma$-carbon (C-15) in a branch chain of compound $\mathbf{1}$ was confirmed by comparing ${ }^{1} \mathrm{H}$ and ${ }^{13} \mathrm{C}$ data with those of 3,19-dihydroxy-15-methoxy-ent-labda-8(17),11,13-trien-16,15-olide. ${ }^{14}$ ) This was further confirmed by the heteronuclear multiple bond correlations (HMBC) between the olefinic proton $\mathrm{H}-14\left(\delta_{\mathrm{H}} 6.78\right)$ and carbons C-13 $\left(\delta_{\mathrm{C}}\right.$ $131.98 / 132.00), \mathrm{C}-15\left(\delta_{\mathrm{C}} 101.94\right)$, and C-16 ( $\left.\delta_{\mathrm{C}} 169.56 / 169.57\right)$; between proton $\mathrm{H}-15\left(\delta_{\mathrm{H}} 5.76\right)$ and $\mathrm{C}-14\left(\delta_{\mathrm{C}} 139.20 / 139.23\right)$, C-16 $\left(\delta_{\mathrm{C}} 169.56 / 169.57\right)$, and methoxy carbon $\left(\delta_{\mathrm{C}} 56.76 / 56.82\right)$ (see Fig. 2). The large coupling constant $\left(J_{11,12}=16.0 \mathrm{~Hz}\right)$ confirmed the $E$ geometry isomerism of the double bond at $\mathrm{C}-11 / \mathrm{C}-12 .{ }^{14)}$ Moreover, in the HMBC spectrum of $\mathbf{1}$, two protons $\mathrm{H}-17\left(\delta_{\mathrm{H}} 4.48\right.$ and 4.76 correlated with $\mathrm{C}-7\left(\delta_{\mathrm{C}}\right.$ 36.74), C-8 ( $\delta_{\mathrm{C}}$ 149.18), and C-9 ( $\delta_{\mathrm{C}}$ 62.28/62.30) suggested that an exocyclic double bond was located at $\mathrm{C}-8 / 17$. The nuclear Overhauser enhancement and exchange spectroscopy (NOESY) correlations between H-19 $\left(\delta_{\mathrm{H}} 0.84\right)$ and $\mathrm{H}-20\left(\delta_{\mathrm{H}}\right.$ $0.87)$ and between H-5 ( $\left.\delta_{\mathrm{H}} 1.09\right)$ and H-9 $\left(\delta_{\mathrm{H}} 2.38\right)$ confirmed both the $\beta$ orientations of methyl and branch chain at C-10 and C-9, respectively. Consequently, compound $\mathbf{1}$ was determined to be 15-methoxylabda-8(17),11E,13-trien-16,15-olide and was named hedycoronen $\mathrm{A}$.

Compound $\mathbf{3}$ was also obtained as a colorless viscous oil. Its basic ion peak at $m / z 331[\mathrm{M}+\mathrm{H}]^{+}$was observed on positive-ion ESI-MS, and HR-ESI-MS analysis revealed the molecular formula to be $\mathrm{C}_{21} \mathrm{H}_{30} \mathrm{O}_{3}$, with a cluster ion peak at $m / z 331.2256[\mathrm{M}+\mathrm{H}]^{+}$(Calcd for $\mathrm{C}_{21} \mathrm{H}_{31} \mathrm{O}_{3}: 331.2273$ ). The ${ }^{1} \mathrm{H}-\mathrm{NMR}$ spectrum of $\mathbf{3}$ (in chloroform- $d_{1}$ ) showed the following signals: three tertiary methyl groups at $\delta_{\mathrm{H}} 0.85,0.87$, and $0.90($ each $3 \mathrm{H}, \mathrm{s})$; one methoxy group at $\delta_{\mathrm{H}} 3.47$ (s); and five olefinic protons at $\delta_{\mathrm{H}} 4.37,4.43,5.89,6.28 / 6.29$, and $6.48 / 6.50$ (see Table 1). The ${ }^{13} \mathrm{C}-\mathrm{NMR}$ and DEPT spectra revealed 21 carbon signals, including four methyl, six methylene, six methine, and five quaternary carbons. The ${ }^{1} \mathrm{H}$ - and ${ }^{13} \mathrm{C}-\mathrm{NMR}$ data of 3 were recognized to be a labdane-type diterpenoid, and compound 3 was isolated as an epimeric mixture at C-16. NMR data of 3 were similar to those of 16-hydroxylabda$8(17), 11,13$-trien-15,16-olide ${ }^{15)}$ except for the replacement of a hydroxyl group by a methoxy group at C-16. An $\alpha, \beta$ unsaturated $\gamma$-lactone with a methoxy group at $\gamma$-carbon (C-16) in a branch chain of compound $\mathbf{3}$ was confirmed by comparing ${ }^{1} \mathrm{H}$ and ${ }^{13} \mathrm{C}$ data with those of 16 -methoxy-6-oxo-7,11,13labdatrien-15,16-olide. ${ }^{16)}$ The HMBC correlations from olefinic proton $\mathrm{H}-11\left(\delta_{\mathrm{H}} 6.48 / 6.50\right)$ to $\mathrm{C}-8\left(\delta_{\mathrm{C}} 148.83 / 148.87\right), \mathrm{C}-9\left(\delta_{\mathrm{C}}\right.$ 


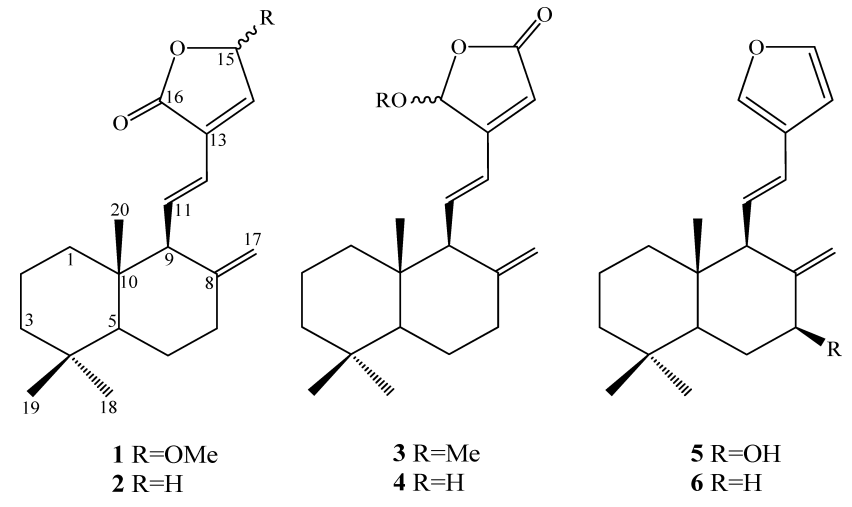

Fig. 1. Structure of Labdanes (1-6) from the Rhizomes of H. coronarium
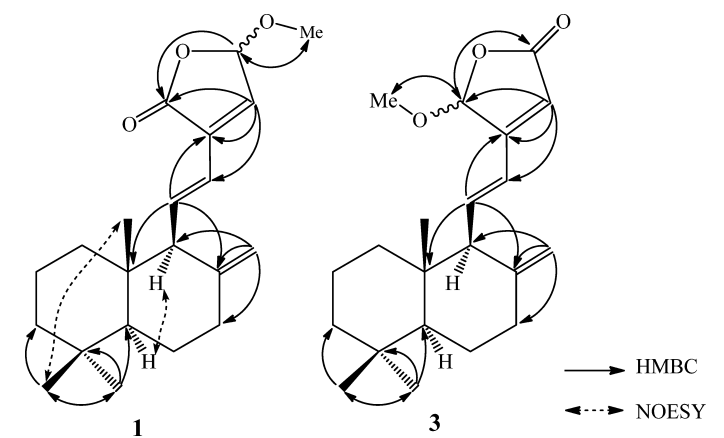

Fig. 2. The Important HMBC and NOESY Correlations of Labdanes 1 and 3

61.96/62.05), C-10 ( $\left.\delta_{\mathrm{C}} 39.50 / 39.58\right), \mathrm{C}-12\left(\delta_{\mathrm{C}} 122.71 / 122.76\right)$, and $\mathrm{C}-13\left(\delta_{\mathrm{C}} 159.18\right)$; from the olefinic proton $\mathrm{H}-14\left(\delta_{\mathrm{H}} 5.89\right)$ to $\mathrm{C}-13\left(\delta_{\mathrm{C}} 159.18\right), \mathrm{C}-15\left(\delta_{\mathrm{C}} 170.68\right)$, and C-16 $\left(\delta_{\mathrm{C}} 102.57 / 102.66\right)$; from proton $\mathrm{H}-16\left(\delta_{\mathrm{H}} 6.00\right)$ to $\mathrm{C}-14\left(\delta_{\mathrm{C}} 116.52 / 116.55\right), \mathrm{C}-15$ $\left(\delta_{\mathrm{C}}\right.$ 170.68), and methoxy carbon $\left(\delta_{\mathrm{C}} 54.30\right)$; from two olefinic protons $\mathrm{H}-17\left(\delta_{\mathrm{H}} 4.37\right.$ and 4.43$)$ to $\mathrm{C}-7\left(\delta_{\mathrm{C}} 36.61\right), \mathrm{C}-8$ $\left(\delta_{\mathrm{C}} 148.83 / 148.87\right)$, and $\mathrm{C}-9\left(\delta_{\mathrm{C}} 61.96 / 62.05\right)$ confirmed that three double bonds, an epoxy bridge and a carbonyl group were at $\mathrm{C} 8 / 17, \mathrm{C} 11 / 12, \mathrm{C} 13 / 14, \mathrm{C} 15 / 16$, and $\mathrm{C}-15$, respectively. Furthermore, the large coupling constant $\left(J_{11,12}=16.0 \mathrm{~Hz}\right)$ confirmed the $E$ geometry isomerism of a double bond at $\mathrm{C}-11 / \mathrm{C}-12{ }^{16)}$ Consequently, compound 3 was determined to be 16-methoxylabda-8(17),11E,13-trien-15,16-olide and was named hedycoronen $\mathrm{B}$.

In addition to the above new compounds, four known compounds were also isolated from the methanol extract. By comparison of their physical and spectroscopic data with literature, they were characterized as labda-8(17),11,13-trien-16(15)-olide (2), ${ }^{8)}$ 16-hydroxylabda-8(17),11,13-trien-15,16-olide (4), ${ }^{15)}$ coronarin $\mathrm{A}(\mathbf{5}){ }^{7)}$ and coronarin E (6) ${ }^{17)}$ (see Fig. 1). To the best our knowledge, this is the first report on the chemical analysis of the isolation of compound $\mathbf{4}$ from Hedychium species.

Continuing with our interest in the evaluation of the biological potential of natural diterpenes and to search novel antiinflammatory agents from natural products, we have evaluated the effects of six labdane-type diterpenoids $(\mathbf{1}-\mathbf{6})$ in the inflammatory response by bone marrow-derived dendritic cells (DCs). We first used a colorimetric 3-(4,5-dimethylthiazol2-yl)-2,5-diphenyltetrazolium bromide (MTT) assay (Sigma, MO, U.S.A.) to confirm that these compounds have no or little

\section{A. TNF- $\alpha$}

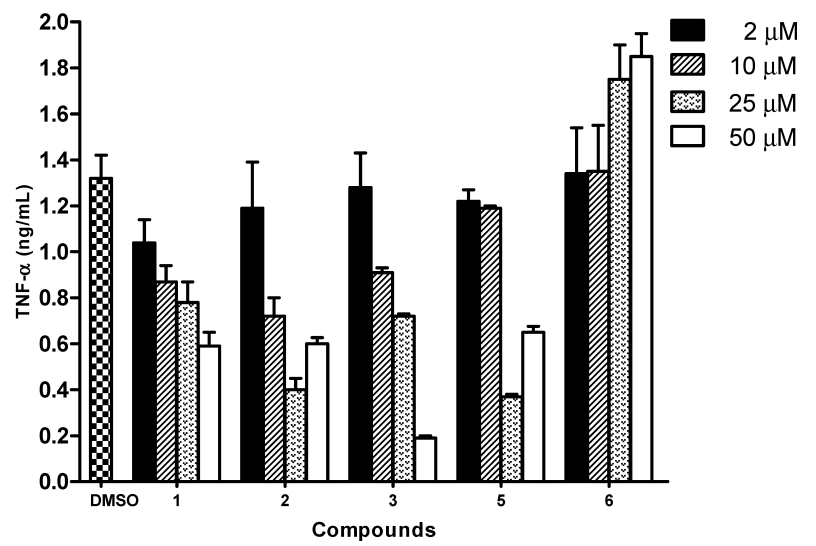

B. IL-6

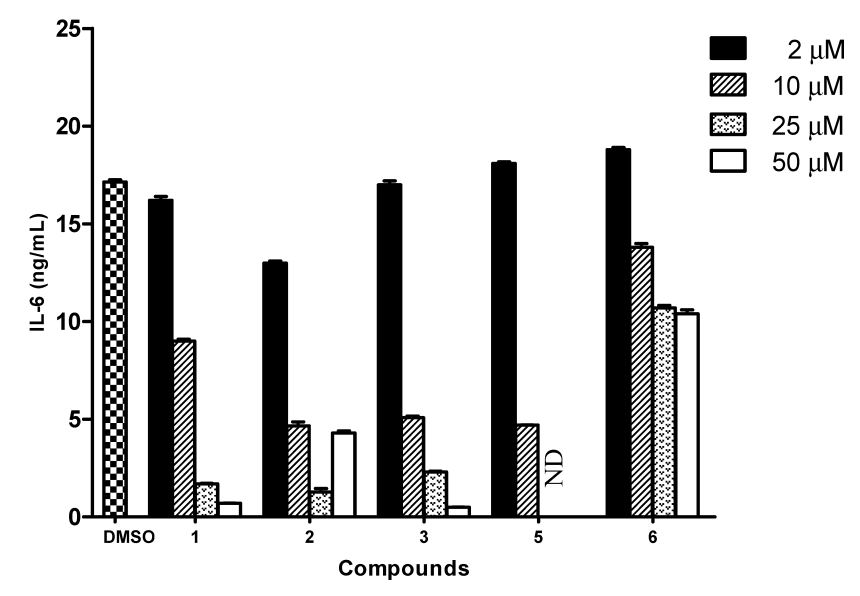

C. IL-12 p40

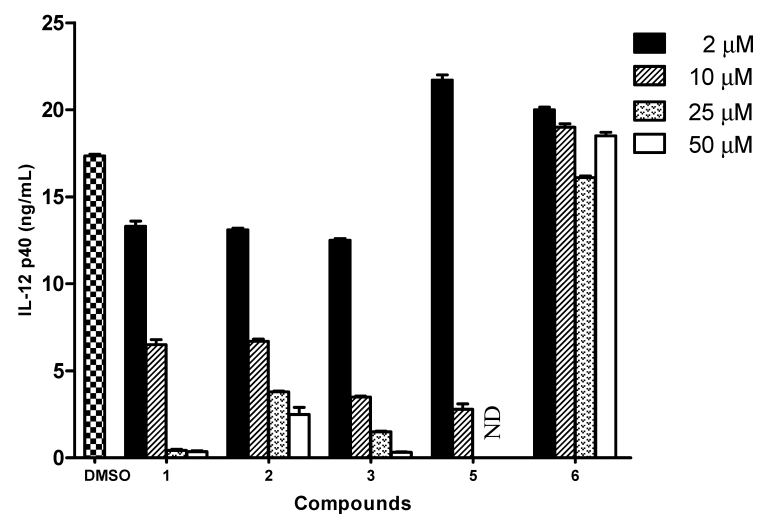

Fig. 3. Effect of Labdanes (1-6) on TNF- $\alpha$ (A), IL-6 (B), and IL-12 p40(C) Production by LPS-Stimulated BMDCs

DCs were treated with the compounds $(2,10,25,50 \mu \mathrm{M})$ for $1 \mathrm{~h}$ before stimulation with LPS $(10 \mathrm{ng} / \mathrm{mL})$. Supernatants were harvested $18 \mathrm{~h}$ after stimulation. Concentrations of murine TNF- $\alpha$, IL- 6 , and IL-12 p40 in the culture supernatants were determined by ELISA. The data were presented as inhibition rate (\%) compared to the value of vehicle-treated DC. ND: Not determined.

effect on the cell viability (data not shown). Compound $\mathbf{4}$ was not further studied due to cytotoxicity. Upon LPS treatment, DCs are known to secrete pro-inflammatory cytokine, including TNF- $\alpha$, IL-6, and IL-12. Pro-inflammatory events include cytokine release, activation, and rapid accumulation of neutro- 
Table 2. Anti-inflammatory Effects of Compounds on LPS-Stimulated Bone Marrow-Derived Dendritic Cells

\begin{tabular}{cccc}
\hline \hline \multirow{3}{*}{ Compound } & \multicolumn{3}{c}{$\mathrm{IC}_{50}(\mu \mathrm{M})$} \\
\cline { 2 - 4 } & $\mathrm{TNF}-\alpha$ & $\mathrm{IL}-6$ & $\mathrm{IL}-12 \mathrm{p} 40$ \\
\hline $\mathbf{1}$ & $46.0 \pm 1.3$ & $9.1 \pm 0.3$ & $5.6 \pm 0.2$ \\
$\mathbf{2}$ & $>100$ & $5.2 \pm 0.1$ & $4.1 \pm 0.2$ \\
$\mathbf{3}$ & $12.7 \pm 0.3$ & $7.7 \pm 0.5$ & $4.3 \pm 0.3$ \\
$\mathbf{5}$ & $>100$ & $\mathrm{ND}$ & $\mathrm{ND}$ \\
$\mathbf{6}$ & $>100$ & $75.0 \pm 0.9$ & $>100$ \\
$\mathrm{SB} 203580$ & $7.2 \pm 0.1$ & $3.5 \pm 0.1$ & $5.0 \pm 0.2$ \\
\hline
\end{tabular}

Values $<100 \mu \mathrm{m}$ are considered to be active. SB203580 was used as a positive control. Data are presented as the mean \pm S.D. Samples run in triplicate. ND: Not determined.

phils, with subsequent recruitment of mononuclear cells. The p38 mitogen-activated protein (MAP) kinase intracellular signaling pathway plays a central role in regulating a wide range of inflammatory responses in many different cells. ${ }^{18)}$

In our experiments, DCs were incubated in 48-well plates at a density of $2 \times 10^{5}$ cells $/ \mathrm{mL}$, and then treated for $1 \mathrm{~h}$ with the compounds at the concentration of $2,10,25$, and $50 \mu \mathrm{m}$, and then stimulated with LPS $(10 \mathrm{ng} / \mathrm{mL})$ (see Fig. 3). Supernatants were harvested $16 \mathrm{~h}$ after stimulation. SB203580, an inhibitor of cytokine suppressive binding protein/p38 kinase, was used as a positive control. SB203580 inhibited TNF- $\alpha$, IL-6, and IL12 production with $\mathrm{IC}_{50}$ of $7.2 \pm 0.1,3.5 \pm 0.1$, and $5.0 \pm 0.2 \mu \mathrm{M}$, respectively (see Table 2). Of these compounds, compounds 1-3, three labdanes contain $\alpha, \beta$-unsaturated $\gamma$-lactone, were the most potent inhibitors of LPS-stimulated IL- 6 and IL-12 production reducing the levels of these cytokines with $\mathrm{IC}_{50}$ ranging from $4.1 \pm 0.2$ to $9.1 \pm 0.3 \mu \mathrm{M}$. Compounds $\mathbf{1}$ and $\mathbf{3}$ showed moderate inhibitory activity on the TNF- $\alpha$ production, with $\mathrm{IC}_{50}$ values of $46.0 \pm 1.3$ and $12.7 \pm 0.3 \mu \mathrm{M}$, respectively. The remains of compounds showed inactivity $\left(\mathrm{IC}_{50}>100 \mu \mathrm{M}\right)$. Some labdane derivatives were proved to be potential antiinflammatory agents. ${ }^{12)}$ In addition, many drugs are commonly used as immunosuppressants, such as cyclosporin $\mathrm{A}$ and dexamethasone, exhibit TNF- $\alpha$ inhibitory properties, although their effects are broad and associated with considerable toxicity. Therefore, natural inhibitors from anti-inflammatory plants that have a minimal side effect profile with stronger inhibitory activity against TNF- $\alpha$ may be useful and effective therapies against LPS-stimulated pro-inflammatory cytokine production.

These findings are consistent with showing that compounds 1-3 inhibit the production of TNF- $\alpha$, IL-6, and IL-12 in LPS-stimulated DCs. Thus, the present study suggests labdane-type diterpenoids $\mathbf{1} \mathbf{-} \mathbf{3}$ isolated from the rhizomes of $H$. coronarium may have potent anti-inflammatory action.

\section{Experimental}

General Experimental Procedures Optical rotations were determined on a Jasco DIP-370 automatic polarimeter. The FT-IR spectra were obtained from a Jasco Report-100 infrared spectrometer. The NMR spectra were recorded using a Bruker DRX 500 spectrometer $\left({ }^{1} \mathrm{H}, 500 \mathrm{MHz} ;{ }^{13} \mathrm{C}, 125 \mathrm{MHz}\right)$. The ESI-MS was obtained on an AGILENT 1200 SERIES LC-MSD Trap spectrometer. The HR-ESI-MS were obtained using a JEOL JMS-T100LC spectrometer. Column chromatog- raphy was performed using silica-gel (Kieselgel 60, 70-230 mesh and $230-400$ mesh, Merck) or YMC RP-18 resins (30-50 $\mu \mathrm{m}$, Fujisilisa Chemical Ltd., Japan), and thin layer chromatography (TLC) was performed using a pre-coated silica-gel $60 \mathrm{~F}_{254}(0.25 \mathrm{~mm}$, Merck $)$ and RP-18 $\mathrm{F}_{254} \mathrm{~S}$ plates (0.25 mm, Merck).

Plant Material The rhizomes of $H$. coronarium were collected at Sapa, Vietnam during January 2010 and were identified by Dr. Ninh Khac Ban, Institute of Marine Biochemistry, VAST, Vietnam. An authentic sample (IMBC-HC10) was deposited at the herbarium of the Institute of Marine Biochemistry, VAST, Vietnam.

Extraction and Isolation The rhizomes of $\mathrm{H}$. coronarium $(1.0 \mathrm{~kg})$ were extracted with $\mathrm{MeOH}$ three times under reflux for $15 \mathrm{~h}$ to yield $90.0 \mathrm{~g}$ of a dark solid extract, which was then suspended in water and successively partitioned with chloroform $\left(\mathrm{CHCl}_{3}\right)$ and ethyl acetate (EtOAc) to obtain $\mathrm{CHCl}_{3}(\mathrm{HC} 1,50.1 \mathrm{~g})$, EtOAc (HC2, $\left.25.3 \mathrm{~g}\right)$, and water (HC3, $14.6 \mathrm{~g})$ extracts after removing the solvent in vacuo. $\mathrm{HCl}$ was chromatographed on a silica gel column and eluted with an $n$-hexane-acetone gradient $(100: 1-1: 1, \mathrm{v} / \mathrm{v})$ to obtain four subfractions, HC1A (15.0 g), HC1B (10.4 g), HC1C (18.7 g), and HC1D $(6.0 \mathrm{~g})$. The HC1B fraction was chromatographed on a silica gel column eluting with $\mathrm{CHCl}_{3}-\mathrm{MeOH}(40: 1$, v/v) to obtain $2(8.0 \mathrm{mg})$ and $\mathbf{6}(6.4 \mathrm{mg})$. The $\mathrm{HClC}$ fraction was further chromatographed on a silica gel column eluting with $\mathrm{CH}_{2} \mathrm{Cl}_{2}-\mathrm{MeOH}(30: 1, \mathrm{v} / \mathrm{v})$ to give three smaller fractions, $\mathrm{HC} 1 \mathrm{C} 1-\mathrm{HC} 1 \mathrm{C} 3$. The $\mathrm{HC} 1 \mathrm{C} 2$ fraction was chromatographed on an YMC RP-18 column eluting with acetone-water $(5: 1$, $\mathrm{v} / \mathrm{v})$ to yield $\mathbf{4}(2.6 \mathrm{mg})$ and $\mathbf{5}(6.0 \mathrm{mg})$. Fraction $\mathrm{HC1C} 2$ was chromatographed on an YMC RP-18 column eluting with $\mathrm{MeOH}$-water $(3: 1, \mathrm{v} / \mathrm{v})$ to yield $\mathbf{1}(7.0 \mathrm{mg})$ and $\mathbf{3}(8.5 \mathrm{mg})$.

Hedycoronen A (1): A colorless oil, $[\alpha]_{\mathrm{D}}^{25}:+19.3^{\circ}(c=0.5$ in $\mathrm{CHCl}_{3}$ ); positive ESI-MS $m / z$ : $331[\mathrm{M}+\mathrm{H}]^{+}$, HR-ESI-MS Found $m / z$ : $331.2268[\mathrm{M}+\mathrm{H}]^{+}$; Calcd $\mathrm{C}_{21} \mathrm{H}_{31} \mathrm{O}_{3}$ for 331.2273), ${ }^{1} \mathrm{H}$ - and ${ }^{13} \mathrm{C}-\mathrm{NMR}$ : see Table 1 .

Hedycoronen B (2): A colorless oil, $[\alpha]_{\mathrm{D}}^{25}:+22.1^{\circ}(c=0.5$ in $\mathrm{CHCl}_{3}$ ); positive ESI-MS $m / z: 331[\mathrm{M}+\mathrm{H}]^{+}$, HR-ESI-MS Found $m / z$ : $331.2256[\mathrm{M}+\mathrm{H}]^{+}$; Calcd $\mathrm{C}_{21} \mathrm{H}_{31} \mathrm{O}_{3}$ for 331.2273), ${ }^{1} \mathrm{H}$ - and ${ }^{13} \mathrm{C}-\mathrm{NMR}$ : see Table 1 .

Cell Culture and Measurement of Cytokine Production Bone marrow-derived DCs were grown from wild-type C57BL/6 mice (Taconic Farm, NY, U.S.A.). Briefly, the mouse tibia and femur was obtained by flushing with Dulbecco's modified Eagle's medium (DMEM) to yield bone marrow cells. The cells were cultured in RPMI 1640 medium containing 10\% heat-inactivated fetal bovine serum (FBS) (Gibco, NY, U.S.A.), $50 \mu \mathrm{m} \quad \beta$-mercaptoethanol, $2 \mathrm{~mm}$ glutamine supplemented with a $3 \% \mathrm{~J} 558 \mathrm{~L}$ hybridoma cell culture supernatant containing granulocyte-macrophage colony-stimulating factor. The culture medium was replaced with fresh medium every second day. At day 6 of culture, non-adherent cells and loosely adherent DC aggregates were harvested, washed, and resuspended in RPMI 1640 supplemented with 5\% FBS.

The DCs were incubated in 48 -well plates in $0.5 \mathrm{~mL}$ containing $1 \times 10^{5}$ cells per well treated with the isolated compounds at a concentration of $2.0,10,25$, and $50 \mu \mathrm{M}$ for $1 \mathrm{~h}$ before stimulation with $10 \mathrm{ng} / \mathrm{mL}$ LPS from Salmonella minnesota (Alexis, NY, U.S.A.). Supernatants were harvested $16 \mathrm{~h}$ after stimulation. Concentrations of murine TNF- $\alpha$, IL6 , IL-12 p40, and in the culture supernatant fraction were 
determined by enzyme-linked immunosorbent assay (ELISA) (Pharmingen, CA, U.S.A.) according to the manufacturer's instructions. The data are presented as means \pm standard deviation (S.D.) of at least three independent experiments performed in triplicate.

Acknowledgments This study was supported by the Priority Research Center Program (2009-0093815) and Basic Science Research Program (2010-0023645) through the National Research Foundation of Korea (NRF) funded by the Ministry of Education, Science and Technology, Republic of Korea.

\section{References}

1) Beutler B., Cerami A., Nature (London), 320, 584-588 (1986).

2) Weinstein D. L., O’Neill B. L., Metcalf E. S., Infect. Immun., 65, 395-404 (1997).

3) Papanicolaou D. A., Wilder R. L., Manolagas S. C., Chrousos G. P., Ann. Intern. Med., 128, 127-137 (1998).

4) Trinchieri G., Pflanz S., Kastelein R. A., Immunity, 19, 641-644 (2003).

5) Gately M. K., Renzetti L. M., Magram J., Stern A. S., Adorini L., Gubler U., Presky D. H., Annu. Rev. Immunol., 16, 495-521 (1998).

6) Mannon P. J., Fuss I. J., Mayer L., Elson C. O., Sandborn W. J., Present D., Dolin B., Goodman N., Groden C., Hornung R. L., Quezado M., Yang Z., Neurath M. F., Salfeld J., Veldman G. M., Schwertschlag U., Strober W., Anti-IL-12 Crohn's Disease Study
Group, N. Engl. J. Med., 351, 2069-2079 (2004).

7) Itokawa H., Morita H., Katou I., Takeya K., Cavalheiro A. J., de Oliveira R. C., Ishige M., Motidome M., Planta Med., 54, 311-315 (1988).

8) Nakatani N., Kikuzaki H., Yamaji H., Yoshio K., Kitora C., Okada K., Padolina W. G., Phytochemistry, 37, 1383-1388 (1994).

9) Suresh G., Reddy P. P., Babu K. S., Shaik T. B., Kalivendi S. V., Bioorg. Med. Chem. Lett., 20, 7544-7548 (2010).

10) Nakamura S., Okazaki Y., Ninomiya K., Morikawa T., Matsuda H., Yoshikawa M., Chem. Pharm. Bull., 56, 1704-1709 (2008).

11) Matsuda H., Morikawa T., Sakamoto Y., Toguchida I., Yoshikawa M., Heterocycles, 56, 45-50 (2002).

12) Girón N., Pérez-Sacau E., López-Fontal R., Amaro-Luis J. M., Hortelano S., Estevez-Braun A., de Las Heras B., Eur. J. Med. Chem., 45, 3155-3161 (2010).

13) Sy L.-K., Brown G. D., J. Nat. Prod., 60, 904-908 (1997).

14) Chen L.-X., Qiu F., Wei H., Qu G.-X., Yao X.-S., Helv. Chim. Acta, 89, 2654-2664 (2006).

15) Mohamad H., Lajis N. H., Abas F., Ali A. M., Sukari M. A., Kikuzaki H., Nakatani N., J. Nat. Prod., 68, 285-288 (2005).

16) Reddy P. P., Tiwari A. K., Rao R. R., Madhusudhana K., Rao V. R. S., Ali A. Z., Babu K. S., Rao J. M., Bioorg. Med. Chem. Lett., 19, $2562-2565$ (2009)

17) Itokawa H., Morita H., Takeya K., Motidome M., Chem. Pharm. Bull., 36, 2682-2684 (1988).

18) Nick J. A., Young S. K., Brown K. K., Avdi N. J., Arndt P. G., Suratt B. T., Janes M. S., Henson P. M., Worthen G. S., J. Immunol., 164, 2151-2159 (2000). 